\title{
Exploring the Determinants of Relationship Quality in Retail Banking Services
}

\author{
Chul Hwan Kwon, Dong Hyuk Jo*, and Hugo Guimarães Mariano \\ Department of Business Administration, Soongsil University \\ Seoul, South Korea \\ [e-mail: chulhk1@hanmail.net, joe@ssu.ac.kr, hg.mariano@hotmail.com] \\ *Corresponding author: Dong Hyuk Jo
}

Received February 23, 2020; revised April 21, 2020; revised June 18, 2020; accepted July 14, 2020;

published August 31, 2020

\begin{abstract}
The rapid change in the financial market has led to a shift to relationship marketing, which emphasizes relationships with existing customers rather than creating new ones. Therefore, to achieve competitive advantage in the market, assessing service quality and relationship quality has become an important tool for financial institutions. The widely applied five dimension model has shown problems of dimensions overlapping and blurring with each other, which results in the lack in providing the marketer with practical administrative implications. Therefore, a three dimensional model, composed of interaction quality, physical environment quality and outcome quality, that could be applied in general to various service industries and, at the same time, categorized into service quality dimensions that are not ambiguous for marketers to manage has been utilized.

As a result, in the case of Korean consumers, interaction quality, physical environment quality, and outcome quality were shown to have positive effects on customer satisfaction and customer loyalty. For Brazilian consumers, physical environment quality and outcome quality were shown to have positive effects on customer satisfaction and customer loyalty. Also, a median effect of customer satisfaction was found. This paper reviews the concept and dimensions of service quality and relationship quality, as well as verifying the structural relationship between the two variables through empirical analysis. Through the results of the analysis, the paper compares the differences between two distinctive countries and present theoretical and academic implications.
\end{abstract}

Keywords: Retail Banking, Relationship Quality, Interaction Quality, Physical Environment Quality, Outcome Quality

A preliminary version of this paper was presented at ICONI 2019, and was selected as an outstanding paper. 


\section{Introduction}

Due to increasing competition in the world of banking, the need for an organization to stand out in the market has been increasing steadily. The industry has been keeping an eye on its services, such as the convenience of its facilities, the cost of products, the variety of product lines, and customer service. In cases of small- and medium-sized banks, customer service has been a key aspect for making their presence in the market. The inability to compete in other areas has led them to focus mainly on customer service as their competitive advantage.

Many banks have directed their strategies toward increasing customer satisfaction (CS) and customer loyalty (CL) through improving service quality [1], under the belief that satisfied customers tend to stay customers and continue their business relationship. More importantly, the cost of maintaining existing customers is less than the cost of gaining new ones. In addition, increasing CS can result in an increased share of the business by making more investments and transactions and thereby raising company revenue and long-term profitability [2].

As customer retention is an important goal in business, the factors that affect customers' perception of the bank and the actions that banks can take to increase positive perception have long been questions that banks need to answer. The service provider's attitude, the behavior toward costumers that leads to CS, and the attitude that customer behaviors create are the three aspects that have been discussed so far.

Former studies of the service industry regarding service quality and customer retention has widely utilized the service quality (SERVQUAL) model by Parasuraman, Zeithaml, and Berry (PZB) in 1988 [3]. However, despite the wide use, criticism regarding the model has constantly been brought up. The widely applied five dimension model has shown problems of dimensions overlapping and blurring with each other, which results in the lack in providing marketers with practical administrative implications. Furthermore, the process of measuring expectations and results separately has established the model to be inefficient. Also, as the emergence of the $4^{\text {th }}$ industrial revolution, competition within the service industry has intensified, taking a turn to relationship marketing and new techniques. Nevertheless, there is a shortage of empirical studies regarding the rapid change. Especially, when it comes to differences in cultural, industrial and developmental levels, studies with analysis and comparisons of marketing strategies between two different groups are in near a state of absence.

Thus this study will utilize the three dimension model of Brady and Cronin (2001) [4], the three dimensions being interaction quality (INTQ), physical environment quality (PHYQ) and outcome quality (OUTQ). Of the three dimensions, OUTQ and INTQ each stands for the technical quality, what the customers obtained by the service, and functional quality, how the customers obtained the service product, two functions that compose the concept of service quality explained by Gronroos (1984) [5]. PHYQ stands for the physical environment of where the service is delivered, being added as the importance of the physical environment in service perception was highlighted [4]. Moreover, this study will further examine the relationship of service quality and relationship quality in the evolving service industry. Furthermore, through the comparison of Korea and Brazil, this study will be able to analyze differences in results caused by the differences in cultural, industrial and developmental levels, providing with practical administrative implications for different circumstances.

This study will examine the relationship between service quality and relationship quality. Specifically, this study will test the effect of INTQ, PHYQ and OUTQ on CS. Next, the effect 
of INTQ, PHYQ and OUTQ on CL will be examined. Finally, the effect of CS on CL will be tested. This paper will review the concept and dimensions of service quality and relationship quality, as well as verifying the structural relationship between the two variables through empirical analysis. Through the results of the analysis, the paper will compare the differences between two distinctive countries and present theoretical and academic implications.

\section{Theoretical Background}

\subsection{Retail Banking Industry}

The Cambridge Dictionary defines retail banks as banks that provides services to the public and small businesses rather than to large companies or organizations [6]. The Oxford English Dictionary defines retail banks as banks offering retail-banking services [7]. The banking services provided by retail banks include provision of savings and transactional accounts, mortgages, personal loans, debit cards, credit cards, and so forth.

Due to the customer base and its character in the retail bank industry, most retail banks make providing outstanding service quality a top priority, for it acts as a measure to both customers' needs and increased competition, establishing a competitive advantage [8]. Interactions with customers being a core business process for retail banking, CS has become a key for success [9, 10]. Al-Hawari (2006) [11] states that a higher level of CS creates improved customer retention as well as a favorable overall image of the bank. However, despite the importance, room for improvement still exists. The World Retail Banking Report 2018 [12] highlights the data from the Capgemini Financial Service Analysis and the Voice of the Customer survey reports of 2018, showing that despite continued investments, banks have not entirely quelled dissatisfaction. In fact, only a little over half of all users said their experience across different bank channels was positive.

More must to be considered when it comes to the retail banking industry. As technology development has taken place, self-service technology is a feature required in the retail banking industry [13]. The 2019 Deloitte Banking and Capital Markets Outlook report highlights how the industry is embracing a mobile-centric customer experience due to the customers' constantly evolving demands across the globe. In addition, recent studies on the retail banking industry have expanded from the USA and Europe to developing countries, providing a wider view of the industry [13-16].

\subsection{Service Quality}

After the scale for SERVQUAL model was introduced by PZB in 1988 [3], the model became the most beloved model for service quality analysis. However, criticism regarding the model has existed. SERVQUAL divides service quality into five dimensions: reliability, responsiveness, empathy, assurance, and tangibles. Of the five dimensions, only reliability belongs to OUTQ, whereas the other four belongs to process quality [17].

In 1992, Cronin and Taylor [18] introduced a new model, SERVPERF, with the slight change that it measures service performance only, instead of also measuring expectations. Their study proved that SERVPERF responds less sensitively to industrial characteristics than SERVQUAL does. Not only have Cronin and Taylor (1992) been presenting modified models of SERVQUAL [18], but other researchers have done so as well [4, 19-23]. Most of these modified models omit measuring expectations, and present new dimensions of outcome quality. In fact, when the dimension of OUTQ was added to models measuring process quality, it was proved that the coefficient of determination and the predictive validity improved [24]. 
Brady and Cronin (2001) [4] developed a model that divides service quality into three dimensions: INTQ, PHYQ, and OUTQ, based on the three-component model of Rust and Oliver (1994) [25] and the service quality hierarchy model of Dabholkar et al. (1996) [26]. In this study, we also believe that Brady and Cronin's dimensions will be universal and reasonable in accordance with prior studies, and the effect of the overall service quality and subdimensional relations will be explored by organizing the service quality dimensions as they recommend.

For the nature of services, the interaction that happens between the service provider and consumer during service often has the largest effect on service quality perceptions [26]. These interactions have long been a key element in service exchanges [27]. In their study, Yi and La (2003) [23] estimated INTQ to be influential on both existing and potential customers. Especially in the case of existing customers, it is shown that INTQ has the greatest influence on CS. In the banking industry, as there is little margin for customization in an already existing financial instrument, existing customers have a sense of satisfaction for the service provided, resulting in OUTQ's influence being limited at a certain level.

Customers who have not purchased a particular service tend to look instead for tangible evidence of what to expect [28]. Physical evidence of the surrounding environment, the "servicescape," often influences the customer's expectations [29]. Crane and Clarke (1988) [30] have already revealed that customers of multiple service industries take service environment as a factor in evaluating service quality. Yi and La (2003) [23] explain that PHYQ is the least affecting dimension of the three in the banking industry, but they also state that PHYQ has more effect on potential customers than on existing customers. They also emphasize that for other service industries, such as hotel services or hospitals, the results may be different.

When it comes to service, since the outcome does not always result in a tangible product, Gronroos (1982) [31] defines it as "what the customer is left with when the production process is finished.” Rust and Oliver (1994) [25] defined the service outcome as the "service product," which consists of the features that customers have evaluated after the service has been provided. For customers of the banking service, both existing and potential customers are affected by the OUTQ [23]. Since Rust and Olive (1994) [25] first presented the three-component concept of service quality, many studies have been conducted, providing empirical evidence. Brady and Cronin (2001) [4] were the first to give empirical evidence to the concept. The research was conducted in the belief that service quality could be divided into three dimensions of outcome, interaction, and environment quality, each having three subdimensions that form the basis of service quality perceptions. Four service industries were selected as sample groups: fast food, photograph developing, amusement parks, and dry cleaning. The results showed that all three dimensions directly contribute to service quality perceptions. Ko and Pastore (2005) [32] proposed and tested a conceptual model of service quality that includes program quality in addition to the original three dimensions presented by Rust and Olive (1994) [25] in recreational sports. The conducted tests showed that the four dimensions compose the overall perception of service quality in recreational sports. Wangchuk (2008) [33] studied the effect of INTQ, OUTQ, environment quality, relationship quality, and demographic characteristics on CL in the banking sector of Bhutan. The results showed that all five dimensions influence CL. Choi and Kim (2012) [34] found that perceptions of INTQ, OUTQ, and peer-to-peer quality influence CS and CL in hospital services. Especially regarding OUTQ, they discovered the median effect of familiarity, meaning that the more the customers get used to the service, the higher the CS effect will be. Also, in cases of technology-based self-service banking, which is not discussed in this study, 
Sindwani and Goel (2016) [35] discovered that some dimensions of service quality have a significant effect on CS and CL.

\subsection{Relationship Quality}

The concept of relationship quality measurement of the level of exchange relationship, which is the degree to which the parties meet the needs and expectations, based on a series of formal experiences that have been satisfactory or not [36]. Relationship quality, as a relational exchange between two parties, including both long-term continuity as well as short-term relationships, has been suggested to serve as a medium between relationship performance and relationship determinants [37]. Jarvelin and Lehtinen (1996) [38] define it as customer recognition on how much a bilateral relationship meets expectations, predictions, goals and desires.

Cho and Jeong (2008) [39] analyzed that the relationship quality, consists of trust and relationship immersion, had an effect on the continuance intention. Seo (2013) [40] studied the components of the relevant quality with confidence and satisfaction in the contact service study between airlines and travel agencies. Kim and Shin (2018) [41] explained in their study that service companies can maintain their relationships with existing customers by utilizing an expanded marketing mix as a marketing tool, strengthening the relationship with customers rather than being selected by customers by providing benefits.

The most commonly accepted definition of CS is the one by Oliver (1981) [42], which defines CS as "the summary of psychological state resulting when the emotion surrounding disconfirmed expectations is coupled with the consumer's prior feelings about the consumption experience.” CS is crucial in a business situation, for it is the key to retaining customers [43]. Satisfied customers tend to have more amicable feelings toward the company, the products it sells, and are less price sensitive. Caruana (2002) [44] found that CS has a median effect between service quality and CL in the banking industry. The importance of this connection is because it can cost the bank up to six times more to attract a new customer than to retain an existing customer.

Since the development of the idea of service quality, there has been an issue as to whether service quality and CS are in fact a same concept or are different concepts [45-47]. Dabholkar (1995) [48] explains that the two concepts are distinguishable in short terms, but they overlap in long terms. However, despite the confusion, it can be confirmed that the two concepts are different based on the definition by Oliver (1981) [42] and PZB (1988) [3, 23].

$\mathrm{CL}$ is the relationship persistence intention that determines a long-term customer relationship [49]. It is the attitude or belief that one will revisit or repurchase based on the evaluation of past experiences of certain products or services [50]. At first, CL was understood as a concept consisting of a single dimension of the attitudinal perspective [51]; in subsequent studies, most researchers agree with a multidimensional concept consisting of an attitudinal perspective and a behavioral perspective [52]. Various studies regarding CL in different industries has been conducted over time. Setiawan and Sayuti (2017) [53] discovered that the variables of service quality, trust, and corporate image affects CS and CL; CS also affects CL for the travel agencies of South Sumatra. Lee (2019) [54] studied the effects of the experiential value of five-star hotels on satisfaction and the intention to patronize them again. The results showed that fantasy was the major leading factor in satisfaction, and that gender characteristics and occupational characteristics play mediating effects between satisfaction and intention toward continuous use. In the retail banking sector, utilizing variables of overall service quality, CS, and CL, Ngo and Nguyen (2016) [1] discovered the effect of service quality and CS on CL and the mediating effect of CS in Vietnam. 


\section{Research Method and Hypotheses}

The purpose of this study is to understand the effect that service quality has on CS and CL in the retail bank industry of Korea and Brazil. The three-factor model of Brady and Cronin (2001) [4] was used in measuring service quality. The model was designed under the belief that service quality will have a positive effect on CS and CL, and CS on CL.

H1: Service quality will have an effect $(+)$ on CS.

H1a: The perception of INTQ will have an effect $(+)$ on CS.

H1b: The perception of PHYQ will have an effect $(+)$ on CS.

H1c: The perception of OUTQ will have an effect $(+)$ on CS.

H2: Service quality will have an effect $(+)$ on CL.

H2a: INTQ will have an effect $(+)$ on CL.

H2b: PHYQ will have an effect $(+)$ on CL.

H2c: OUTQ will have an effect $(+)$ on CL.

H3: CS will have an effect (+) on CL.

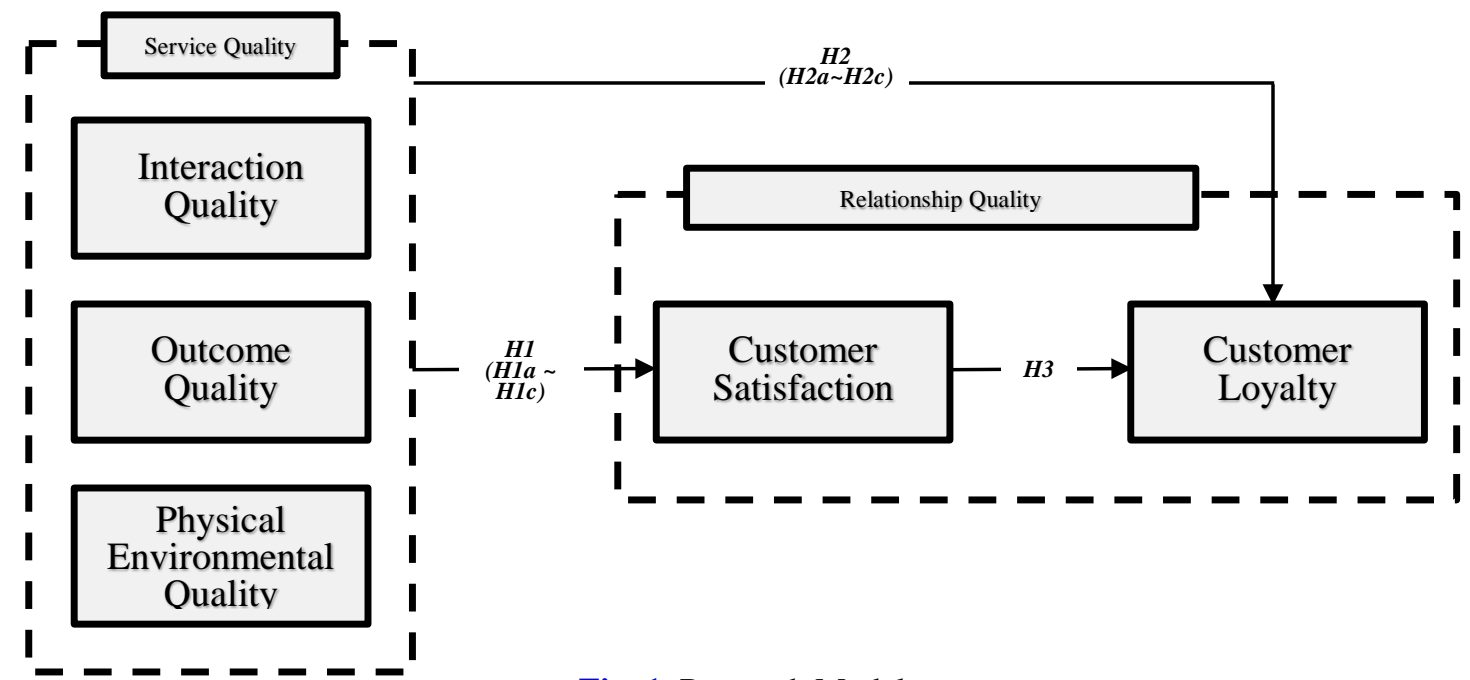

Fig. 1. Research Model

\section{Analysis and Results}

\subsection{Sample}

A total of 410 samples were drawn from those who have experienced offline banking services in Korea or Brazil. Of the 410, 206 were collected from Brazil and 204 from Korea. An empirical statistical analysis was conducted using SPSS 25.0 to verify the hypotheses. The profile of respondents are as follows. 
Table 1. Sample Characters

\begin{tabular}{|c|c|c|c|c|c|}
\hline \multicolumn{2}{|c|}{ Category and Items } & \multicolumn{2}{c|}{ Korea (N=204) } & \multicolumn{2}{c|}{ Brazil (N=206) } \\
\cline { 3 - 6 } & & Sample Size & Ratio (\%) & Sample Size & Ratio (\%) \\
\hline \multirow{3}{*}{ Gender } & Male & 117 & 57.4 & 129 & 62.0 \\
& Female & 87 & 42.6 & 77 & 37.0 \\
\hline \multirow{5}{*}{ Age } & $20-29$ & 144 & 70.6 & 94 & 45.2 \\
& $30-39$ & 30 & 14.7 & 53 & 25.5 \\
& $40-49$ & 20 & 9.8 & 30 & 14.4 \\
& $>=50$ & 10 & 4.9 & 29 & 13.9 \\
\hline \multirow{5}{*}{ Occupation } & Student & 128 & 62.7 & 29 & 13.9 \\
& Office/Managerial & 33 & 16.2 & 50 & 31.7 \\
& Specialist & 13 & 6.4 & 11 & 5.3 \\
& Self-employed & 8 & 3.9 & 32 & 15.4 \\
& Sales/Service & 7 & 3.4 & 18 & 8.7 \\
& Others & 15 & 7.4 & 66 & 24 \\
\hline
\end{tabular}

\subsection{Validity and Reliability}

To examine the variables of the study, both factor analysis and reliability analysis were conducted. Except for PQ5 and OQ1, all other variables showed a factor loading ranging from .702 to .944 , securing validity. The reliability of the variables was measured by Cronbach's $\alpha$, ranging from .823 to .938 , assuring a satisfactory level.

Table 2. Validity and Reliability

\begin{tabular}{|c|c|c|c|}
\hline \multicolumn{2}{|c|}{ Variables } & Factor Loading & Cronbach's Alpha \\
\hline \multirow{5}{*}{ INTQ } & IQ1 & .801 & \multirow{5}{*}{.912} \\
\hline & IQ2 & .770 & \\
\hline & IQ3 & .807 & \\
\hline & IQ4 & .854 & \\
\hline & IQ5 & .812 & \\
\hline \multirow{4}{*}{ PHYQ } & PQ1 & .790 & \multirow{4}{*}{.823} \\
\hline & PQ2 & .823 & \\
\hline & PQ3 & .706 & \\
\hline & PQ4 & .674 & \\
\hline \multirow{4}{*}{ OUTQ } & OQ2 & .702 & \multirow{4}{*}{.827} \\
\hline & OQ3 & .676 & \\
\hline & OQ4 & .851 & \\
\hline & OQ5 & .791 & \\
\hline \multirow{5}{*}{ CS } & CS1 & .917 & \multirow{5}{*}{.938} \\
\hline & CS2 & .894 & \\
\hline & CS3 & .894 & \\
\hline & CS4 & 879 & \\
\hline & CS5 & .897 & \\
\hline \multirow{4}{*}{ CL } & CL1 & .944 & \multirow{4}{*}{.917} \\
\hline & CL2 & 929 & \\
\hline & CL3 & .891 & \\
\hline & CL4 & .833 & \\
\hline
\end{tabular}




\subsection{Correlation Analysis}

The correlations of the constructs were analyzed, showing positive (+) relationships between all constructs.

Table 3. Correlation Analysis

\begin{tabular}{|c|c|c|c|c|c|}
\hline Variables & $\mathbf{1}$ & $\mathbf{2}$ & $\mathbf{3}$ & $\mathbf{4}$ & $\mathbf{5}$ \\
\hline 1. INTQ & 1 & & & & \\
\hline 2. PHYQ & $.536^{* *}$ & 1 & & & \\
\hline 3.OUTQ & $.519^{* *}$ & $.468^{* *}$ & 1 & & \\
\hline 4. CS & $.640^{* *}$ & $.588^{* *}$ & $.743^{* *}$ & 1 & \\
\hline 5. CL & $.513^{* *}$ & $.500^{* *}$ & $.630^{* *}$ & $.852^{* *}$ & 1 \\
\hline
\end{tabular}

$* \mathrm{p}<0.05, * * \mathrm{p}<0.01$

\subsection{Hypotheses Test}

Table 4 is a hierarchical regression model of the variables that affect CS. First, Model 1 shows that INTQ explains $41 \%$ of the variation of CS, and that the higher the perception of INTQ, the higher the CS is $(\mathrm{t}=16.832, p=.000)$. Model 2, which adds PHYQ to Model 1, explains the variation of CS 8.4\% better compared to Model 1 . Also, it is shown that both INTQ ( $\mathrm{t}=10.925$, $p=.000)$ and PHYQ $(\mathrm{t}=8.214, p=.000)$ have an effect. Model 3 is the result of regression analysis with the addition of OUTQ to model 2. Model 3 explains $66.9 \%$ of the variation of CS, $17.5 \%$ higher than model 2. All three INTQ $(\mathrm{t}=7.325, p=.000)$, PHYQ $(\mathrm{t}=5.918, p=.000)$, and OUTQ $(\mathrm{t}=14.677, p=.000)$ are shown to affect CS. When assessing the relative influence that could better improve CS, OUTQ $(\beta=.508)$ was shown to have the most influence, followed by INTQ $(\beta=.265)$, and PHYQ $(\beta=.207)$.

Table 4. Quality and CS Relationship Verification Results (All)

\begin{tabular}{|c|c|c|c|c|c|c|c|c|c|}
\hline & \multicolumn{3}{|c|}{ Model 1} & \multicolumn{3}{|c|}{ Model 2} & \multicolumn{3}{|c|}{ Model 3} \\
\hline & SE & $\beta$ & t-value & SE & $\beta$ & t-value & SE & $\boldsymbol{\beta}$ & t-value \\
\hline IQ & .041 & .640 & $\begin{array}{c}16.832 \\
(.000)\end{array}$ & .045 & .456 & $\begin{array}{r}10.925 \\
(.000)\end{array}$ & .039 & .265 & $\begin{array}{l}7.325 \\
(.000)\end{array}$ \\
\hline$P Q$ & & & & .047 & .343 & $\begin{array}{l}8.214 \\
(.000)\end{array}$ & .039 & .207 & $\begin{array}{l}5.918 \\
(.000)\end{array}$ \\
\hline \multirow[t]{2}{*}{ OQ } & & & & & & & .036 & .508 & $\begin{array}{c}14.677 \\
(.000)\end{array}$ \\
\hline & \multicolumn{3}{|c|}{$\begin{array}{c}R^{2}=.410 \\
\mathrm{~F}=283.317 \\
p=.000\end{array}$} & \multicolumn{3}{|c|}{$\begin{array}{c}R^{2}=.494, \\
\mathrm{~F}=198.465, \\
p=.000\end{array}$} & \multicolumn{3}{|c|}{$\begin{array}{c}R^{2}=.669 \\
\mathrm{~F}=273.828 \\
p=.000\end{array}$} \\
\hline
\end{tabular}


When considering Korea, except for Model 3 explaining the variation of CS $10.2 \%$ less, the results showed a similar aspect, with OUTQ $(\beta=.440)$ having the most influence, followed by $\operatorname{INTQ}(\beta=.338)$, and PHYQ $(\beta=.181)$.

Table 5. Service Quality and CS Relationship Verification Results (Korea)

\begin{tabular}{|c|c|c|c|c|c|c|c|c|c|}
\hline & \multicolumn{3}{|c|}{ Model 1 } & \multicolumn{3}{c|}{ Model 2 } & \multicolumn{3}{c|}{ Model 3 } \\
\cline { 2 - 10 } & SE & $\boldsymbol{\beta}$ & t-value & SE & $\boldsymbol{\beta}$ & t-value & SE & $\boldsymbol{\beta}$ & t-value \\
\hline IQ & .068 & .584 & $\begin{array}{c}10.238 \\
(.000)\end{array}$ & .071 & .455 & $\begin{array}{c}7.569 \\
(.000)\end{array}$ & .063 & .338 & $\begin{array}{c}6.314 \\
(.000)\end{array}$ \\
\hline PQ & & & .060 & .297 & $\begin{array}{c}4.935 \\
(.000)\end{array}$ & .053 & .181 & $\begin{array}{c}3.379 \\
(.001)\end{array}$ \\
\hline OQ & & & & & .051 & .440 & $\begin{array}{c}8.458 \\
(.000)\end{array}$ \\
\hline & \multicolumn{3}{|c|}{$R^{2}=.342}$, \\
& & & \multicolumn{3}{c|}{$\begin{array}{c}R^{2}=.413, \\
\mathrm{~F}=70.640, \\
p=.000\end{array}$} & \multicolumn{3}{c|}{$\begin{array}{c}R^{2}=.567, \\
\mathrm{~F}=87.461, \\
p=.000\end{array}$} \\
\hline
\end{tabular}

In the case of Brazil, Model 3 explained the variation of CS 6.8\% better. For each variable, OUTQ ( $\beta=.610$ ) was found to have the most affect, followed by physical INTQ ( $\beta=.268)$. However, INTQ $(\mathrm{t}=1.820, p=.070)$ was found to not have an effect under the statistical significance level.

Table 6. Service Quality and CS Relationship Verification Results (Brazil)

\begin{tabular}{|c|c|c|c|c|c|c|c|c|c|}
\hline & \multicolumn{3}{|c|}{ Model 1} & \multicolumn{3}{|c|}{ Model 2} & \multicolumn{3}{|c|}{ Model 3} \\
\hline & SE & $\beta$ & t-value & SE & $\beta$ & t-value & SE & $\beta$ & t-value \\
\hline IQ & .059 & .660 & $\begin{array}{c}12.564 \\
(.000)\end{array}$ & .070 & .410 & $\begin{array}{l}6.527 \\
(.000)\end{array}$ & .059 & .097 & $\begin{array}{l}1.820 \\
(.070)\end{array}$ \\
\hline$P Q$ & & & & .074 & 391 & $\begin{array}{l}6.225 \\
(.000)\end{array}$ & .057 & .269 & $\begin{array}{l}5.621 \\
(.000)\end{array}$ \\
\hline \multirow[t]{2}{*}{ OQ } & & & & & & & .051 & .610 & $\begin{array}{c}12.710 \\
(.000)\end{array}$ \\
\hline & \multicolumn{3}{|c|}{$\begin{array}{c}R^{2}=.436 \\
\mathrm{~F}=157.857 \\
p=.000\end{array}$} & \multicolumn{3}{|c|}{$\begin{array}{c}R^{2}=.527 \\
\mathrm{~F}=112.905 \\
p=.000\end{array}$} & \multicolumn{3}{|c|}{$\begin{array}{c}R^{2}=.737 \\
\mathrm{~F}=188.645 \\
p=.000\end{array}$} \\
\hline
\end{tabular}

Table 7 is a hierarchical regression model of the variables of service quality that affect CL. First, Model 1 shows that INTQ explains 26.3\% of the variation of CL, and that the higher the perception of INTQ, the higher the CL is $(\mathrm{t}=12.060, p=.000)$. Model 2, with the addition of PHYQ to Model 1, explains the variation of CL 7.1\% better compared to Model 1. Also, it is shown that both INTQ $(\mathrm{t}=7.159, p=.000)$ and PHYQ $(\mathrm{t}=6.613, p=.000)$ have an effect. Model 3 is the result of regression analysis with the addition of OUTQ to Model 2. Model 3 explains $47 \%$ of the variation of CL, being $13.6 \%$ higher than Model 2. All three INTQ ( $\mathrm{t}=$ 3.813, $p=.000)$, PHYQ $(\mathrm{t}=4.449, p=.000)$, and OUTQ $(\mathrm{t}=10.208, p=.000)$ are shown to affect CL. When assessing the relative influence that could improve CL, OUTQ $(\beta=.447)$ was shown to have the most influence, followed by PHYQ $(\beta=.197)$, and INTQ $(\beta=.175)$. 
Table 7. Service Quality and CL Relationship Verification Results (All)

\begin{tabular}{|c|c|c|c|c|c|c|c|c|c|}
\hline & \multicolumn{3}{|c|}{ Model 1} & \multicolumn{3}{|c|}{ Model 2} & \multicolumn{3}{|c|}{ Model 3} \\
\hline & SE & $\beta$ & t-value & SE & $\beta$ & t-value & SE & $\boldsymbol{\beta}$ & t-value \\
\hline IQ & .053 & .513 & $\begin{array}{l}12.060 \\
(.000)\end{array}$ & .060 & .343 & $\begin{array}{l}7.159 \\
(.000)\end{array}$ & .057 & .175 & $\begin{array}{l}3.813 \\
(.000)\end{array}$ \\
\hline PQ & & & & .061 & .317 & $\begin{array}{l}6.613 \\
(.000)\end{array}$ & .057 & .197 & $\begin{array}{l}4.449 \\
(.000)\end{array}$ \\
\hline \multirow[t]{2}{*}{ OQ } & & & & & & & .052 & .447 & $\begin{array}{r}10.208 \\
(.000)\end{array}$ \\
\hline & \multicolumn{3}{|c|}{$\begin{array}{c}R^{2}=.263 \\
\mathrm{~F}=145.443 \\
p=.000\end{array}$} & \multicolumn{3}{|c|}{$\begin{array}{c}R^{2}=.334 \\
\mathrm{~F}=102.202 \\
p=.000\end{array}$} & \multicolumn{3}{|c|}{$\begin{array}{c}R^{2}=.470 \\
\mathrm{~F}=120.145 \\
p=.000\end{array}$} \\
\hline
\end{tabular}

When considering Korea, Model 3 explained the variation of CL 7.1\% less. For each variable, OUTQ $(\beta=.417)$ had the most influence, followed by INTQ $(\beta=.228)$, and PHYQ $(\beta=.150)$.

Table 8. Service Quality and CL Relationship Verification Results (Korea)

\begin{tabular}{|c|c|c|c|c|c|c|c|c|c|}
\hline & \multicolumn{3}{|c|}{ Model 1} & \multicolumn{3}{|c|}{ Model 2} & \multicolumn{3}{|c|}{ Model 3} \\
\hline & SE & $\beta$ & t-value & $\mathrm{SE}$ & $\boldsymbol{\beta}$ & t-value & SE & $\beta$ & t-value \\
\hline IQ & .081 & 453 & $\begin{array}{l}7.214 \\
(.000)\end{array}$ & .087 & .339 & $\begin{array}{l}5.023 \\
(.000)\end{array}$ & .081 & 228 & $\begin{array}{l}3.614 \\
(.000)\end{array}$ \\
\hline PQ & & & & .073 & .260 & $\begin{array}{l}3.854 \\
(.000)\end{array}$ & .068 & 150 & $\begin{array}{l}2.383 \\
(.018)\end{array}$ \\
\hline \multirow[t]{2}{*}{ OQ } & & & & & & & .066 & 417 & $\begin{array}{l}6.799 \\
(.000)\end{array}$ \\
\hline & \multicolumn{3}{|c|}{$\begin{array}{c}R^{2}=.205 \\
\mathrm{~F}=52.039 \\
p=.000\end{array}$} & \multicolumn{3}{|c|}{$\begin{array}{c}R^{2}=.260 \\
\mathrm{~F}=35.230 \\
p=.000\end{array}$} & \multicolumn{3}{|c|}{$\begin{array}{c}R^{2}=.399 \\
\mathrm{~F}=44.182 \\
p=.000\end{array}$} \\
\hline
\end{tabular}

For Brazil, Model 3 explained the variation of CL 73.7\% more. For each variable, OUTQ ( $\beta$ $=.502)$ was found to have the greatest affect, followed by physical INTQ $(\beta=.262)$. However, INTQ $(\mathrm{t}=.697, p=.487)$ was found to not have an effect under the statistical significance level.

Table 9. Service Quality and CL Relationship Verification Results (Brazil)

\begin{tabular}{|c|c|c|c|c|c|c|c|c|c|}
\hline & \multicolumn{3}{|c|}{ Model 1 } & \multicolumn{3}{c|}{ Model 2 } & \multicolumn{3}{c|}{ Model 3 } \\
\cline { 2 - 10 } & SE & $\boldsymbol{\beta}$ & t-value & SE & $\boldsymbol{\beta}$ & t-value & SE & $\boldsymbol{\beta}$ & t-value \\
\hline IQ & .078 & .540 & $\begin{array}{c}9.168 \\
(.000)\end{array}$ & .096 & .308 & $\begin{array}{c}4.250 \\
(.000)\end{array}$ & .096 & .050 & $\begin{array}{c}.697 \\
(.487)\end{array}$ \\
\hline PQ & & & .102 & .363 & $\begin{array}{c}4.998 \\
(.000)\end{array}$ & .091 & .262 & $\begin{array}{c}4.018 \\
(.000)\end{array}$ \\
\hline OQ & \multicolumn{3}{|c|}{} & & \multicolumn{3}{c|}{$R^{2}=.436}$, \\
\hline
\end{tabular}


Table 10 is a regression model of the effect that CS has on CL. The results show that CS explains $72.6 \%$ of the variation of CL, verifying the effect of CS $(t=32.867, p=.000)$ on CL.

Table 10. Regression of CS and CL (All)

\begin{tabular}{|c|c|c|c|c|}
\hline $\begin{array}{c}\text { Independent } \\
\text { Variables }\end{array}$ & SE & $\boldsymbol{\beta}$ & t-value & Statistics \\
\hline CS & .03 & .852 & $32.867(.000)$ & $\begin{array}{c}R^{2}=.726, \\
\mathrm{~F}=1080.246, \\
p=.000\end{array}$ \\
\hline
\end{tabular}

For Korea, CS explained 66\% of the variation of CL, also verifying the effect of CS ( $\mathrm{t}=19.819$, $p=.000)$ on CL.

Table 11. Regression of CS and CL (Korea)

\begin{tabular}{|c|c|c|c|c|}
\hline $\begin{array}{c}\text { Independent } \\
\text { Variables }\end{array}$ & SE & $\boldsymbol{\beta}$ & t-value & Statistics \\
\hline CS & .045 & .813 & $\begin{array}{c}19.819 \\
(.000)\end{array}$ & $\begin{array}{c}R^{2}=.660, \\
\mathrm{~F}=392.778, \\
p=.000\end{array}$ \\
\hline
\end{tabular}

For Brazil, CS explained 75.8\% of the variation of CL, also verifying the effect of CS $(\mathrm{t}=$ 25.246, $p=.000)$ on CL.

Table 12. Regression of CS and CL (Brazil)

\begin{tabular}{|c|c|c|c|c|}
\hline $\begin{array}{c}\text { Independent } \\
\text { Variables }\end{array}$ & SE & $\boldsymbol{\beta}$ & t-value & Statistics \\
\hline CS & .041 & .870 & $\begin{array}{c}25.246 \\
(.000)\end{array}$ & $\begin{array}{c}R^{2}=.758, \\
\mathrm{~F}=637.349 \\
p=.000\end{array}$ \\
\hline
\end{tabular}

In addition, to verify the median effect of CS between service quality and CL, a medial regression analysis was conducted. The results are shown on Table 13.

In the first stage, all three dimensions-INTQ $(\beta=.265)$, PHYQ $(\beta=.207)$, and OUTQ ( $\beta$ $=.506$ ) - were shown to affect CS. In the second stage, all three dimensions of INTQ ( $\beta$ $=.175)$, PHYQ $(\beta=.197)$, and OUTQ $(\beta=.447)$ were also shown to affect CL. In the final stage, it is shown that CS $(\beta=.882)$ affects $C L$, meeting the condition for a medial effect. For all three dimensions INTQ $(\beta=-.059<.175)$, PHYQ $(\beta=.014<.197)$, and OUTQ $(\beta=-.001$ $<.447$ ), the standardized regression coefficients of the third stage were shown to be less than the standardized regression coefficients of the second stage, appearing to have mediating effects. More specifically, since all three dimensions of INTQ ( $\beta=-.059)$, PHYQ $(\beta=.014)$, and OUTQ ( $\beta=-.001)$ were shown to not affect CL, all three have complete mediation. 
Table 13. Median effect of CS (All)

\begin{tabular}{|c|c|c|c|}
\hline & $\begin{array}{c}\text { Step 1 } \\
\text { (CS) }\end{array}$ & $\begin{array}{c}\text { Step 2 } \\
\text { (CL) }\end{array}$ & $\begin{array}{c}\text { Step 3 } \\
\text { (CL) }\end{array}$ \\
\hline IQ & $.288(.265)$ & $.217(.175)$ & $-.074(-.059)$ \\
PQ & $.232(.207)$ & $.253(.197)$ & $.018(.014)$ \\
OQ & $.529(.508)$ & $.533(.447)$ & $-.001(-.001)$ \\
\hline CS & & & $1.010(.882)$ \\
\hline & $R^{2}=.669$, & $R^{2}=.470$, & $R^{2}=.728$, \\
Statistics & $\mathrm{F}=273.828$, & $\mathrm{F}=120.145$, & $\mathrm{F}=270.715$, \\
& $p=.000$ & $p=.000$ & $p=.000$ \\
\hline
\end{tabular}

\section{Conclusion}

This study was designed to examine the effect of service quality on the CS and CL of the customers of retail bank industries. Samples were collected from two distinct sample groups in Korea and Brazil in the hope of comparing two distinct parties to find similarities and differences. Service quality dimensions were divided into three factors in accordance with the three-dimensional model [4]. The results were summarized as follows.

For the results of all samples combined, it is shown that all three dimensions of service quality influence CS and CL. More specifically, the OUTQ dimension had the highest effect on CS, INTQ, and PHYQ. For CL, the OUTQ dimension had the highest effect, followed by PHYQ and INTQ. This means that customers of retail banks consider the outcome the most important, and decide to continue their relationship with the bank based on outcomes such as interest rates. The reason INTQ and PHYQ was shown to be less effective may be explained based on the characteristics of the industry. For service products provided in a complete form, there is less of a margin for the service provider to make a difference in the final product. In other words, regardless of who the service provider is, friendly or not, the final OUTQ is quite similar. In different service industries, such as hotels, INTQ may not be as effective as for the retail banking industry. Also, for PHYQ, it can be understood that the difference in the physical environment provided by different banks is relatively small, or that most retail banks meet the standard required by customers. In addition, it was shown that after the mediating effect of CS, service quality had a much higher effect on CL.

With separate samples from Korea and Brazil, the results from Korea were similar to the results of the combined samples, with the exception of INTQ having a higher effect on CL compared to PHYQ; however, the results from Brazil were slightly different-for both CS and CL, INTQ was shown to not affect both variables. In other words, it was found that customers in Brazil put more interest in OUTQ and PHYQ and consider INTQ to be less important. These differences in results may be explained by the varying characteristics of the two distinct sample groups. However, both sample groups, despite their differences, have the greatest interest in OUTQ, strengthening the speculations about the results shown.

This study was able to review the concept and dimensions of service quality and relationship quality, as well as verifying the structural relationship between the two variables through empirical analysis. Through the results of the analysis, the study compared the differences 
between two distinctive countries and presented theoretical and academic implications. However, the study has its limitations in that it was unable to cover Internet-based banks, and in that this study was limited to physical banks alone. Because more and more customers now use Internet banks more commonly, and that more banks are abandoning their physical branches, in future studies, Internet-based banks should also be considered for more accurate results. Also, for the data was restricted only to Korea and Brazil, there are possibilities for cultural singularity, the data from the two countries may not correspond with the world trend, possibly resulting in incorrect generalization. Future studies with different datasets should be done for clarification and further generalization.

\section{References}

[1] Levesque, T. and McDougall, G. H., "Determinants of CS in retail banking," International Journal of Bank Marketing, Vol. 14, No. 7, pp. 12-20, 1996. Article (CrossRef Link)

[2] Jones, T. and Taylor, S. F., "The conceptual domain of service loyalty: How many dimensions?," Journal of Services Marketing, Vol. 21, No. 1, pp. 36-51, 2007. Article (CrossRef Link)

[3] Parasuraman, A., Zeithaml, V. A. and Berry, L. L., "Servqual: A multiple-item scale for measuring consumer perceptions of Service Quality,” Journal of Retailing, vol. 64, no. 1, pp. 12, 1988. Article (CrossRef Link)

[4] Brady, M. K. and Cronin Jr, J. J., "Some new thoughts on conceptualizing perceived service quality: A hierarchical approach,” Journal of Marketing, Vol. 65, no. 3, pp. 34-49, 2001. Article (CrossRef Link)

[5] Gronroos, Christian. "A service quality model and its marketing implications," European Journal of Marketing, vol.18, no. 4, pp. 36-44, 1984. Article (CrossRef Link)

[6] C. J. Cassidy, Cambridge Dictionary of American English, $2^{\text {nd }}$ Edition, Cambridge University Press, 2007.

[7] J. A. Simpson and E. S. C. Weiner, The Oxford English Dictionary, $2^{\text {nd }}$ Edition, Oxford University Press, New York, 1989.

[8] Howcroft, J. B., “CS in retail banking,” Service Industries Journal, vol. 11, no. 1, pp. 11-17, 1991. Article (CrossRef Link)

[9] Chavan, J. and Ahmad, F., "Factors affecting on CS in retail banking: An empirical study," International Journal of Business and Management Invention, vol. 2, no. 1, pp. 55-62, 2013. Article (CrossRef Link)

[10] Belas, J. and Gabcova, L., "Reasons for satisfaction and dissatisfaction of bank customers. Study from Slovakia and the Czech Republic.,” International Journal of Entrepreneurial Knowledge, vol. 2, no. 1, 2014. Article (CrossRef Link)

[11] Al-Hawari, M., "The effect of automated service quality on bank financial performance and the mediating role of customer retention,” Journal of Financial Services Marketing, vol. 10, no. 3, pp. 228-243, 2006. Article (CrossRef Link)

[12] Capgemini \& Efma, World Retail Banking Report 2018, Retrieved from 2018. Article (CrossRef Link)

[13] Iberahim, H., Taufik, N. M., Adzmir, A. M. and Saharuddin, H., "CS on reliability and responsiveness of self-service technology for retail banking services," Procedia Economics and Finance, vol. 37, pp. 13-20, 2016. Article (CrossRef Link)

[14] Ngo, V. M., "The relationship between service quality, CS and CL: An investigation in Vietnamese retail banking sector,” Journal of Competitiveness, pp. 423- 434, 2016. Article (CrossRef Link)

[15] Zungu, N. P. and Mason, R. B., "Young clients' attitudes to service quality at retail banks in a developing country,” Banks and bank systems (Online), vol. 12, no. 1, pp. 44-53, 2017. Article (CrossRef Link) 
[16] Moisescu, O. I., "From CSR to CL: An empirical investigation in the retail banking industry of a developing country,” Scientific Annals of Economics and Business, vol. 64, no. 3, pp. 307-323, 2017. Article (CrossRef Link)

[17] Yi, Y. J. and Lee, J. Y., “A reexamination of the measurement and consequences of service quality: Development and application of the KS-SQI model,” Korean Marketing Review, vol. 16, no. 1, pp. 1-26, 2001. Article (CrossRef Link)

[18] Cronin Jr, J. J. and Taylor, S. A., "Measuring service quality: a reexamination and extension," Journal of Marketing, Vol. 56, no. 3, pp. 55-68, 1992. Article (CrossRef Link)

[19] Boulding, W., Kalra, A., Staelin, R. and Zeithaml, V. A., "A dynamic process model of service quality: From expectations to behavioral intentions,” Journal of Marketing Research, Vol. 30, no. 1, pp. 7-27, 1993. Article (CrossRef Link)

[20] DeSarbo, W. S., Huff, L., Rolandelli, M. and Choi, J., "Chapter 9: On the measurement of perceived service quality: A conjoint analysis approach,” Service quality: New directions in theory and practice, pp. 201-22, 1994. Article (CrossRef Link)

[21] Parasuraman, A., Berry, L. L. and Zeithaml, V. A., "Refinement and reassessment of the SERVQUAL scale,” Journal of Retailing, Vol. 67, no. 4, pp. 420, 1991. Article (CrossRef Link)

[22] Zeithaml, V. A., Berry, L. L. and Parasuraman, A., "The behavioral consequences of service quality,” Journal of Marketing, Vol. 60, no. 2, pp. 31-46, 1996. Article (CrossRef Link)

[23] Yi, Y. and La, S., "The relative effects of three dimensions of service quality on CS-A comparative study of existing vs. potential customers," Journal of Korean Marketing Association, Vol. 18, no. 4, pp. 67-97, 2003. Artible (CrossRef Link)

[24] Richard, M. D. and Allaway, A. W., "Service quality attributes and choice behavior," Journal of Services Marketing, vol. 7, no. 1, pp. 59-68, 1993. Article (CrossRef Link)

[25] Rust, R. T. and Oliver, R. L., "Chapter 1: Service quality: Insights and managerial implications from the frontier,” Service quality: New directions in theory and practice, pp. 1-19, 1994. Article (CrossRef Link)

[26] Dabholkar, P. A., Thorpe, D. I. and Rentz, J. O., “A measure of service quality for retail stores: Scale development and validation,” Journal of the Academy of Marketing Science, Vol. 24, no.1, pp. 3, 1996. Article (CrossRef Link)

[27] Czepiel, J. A., "Service encounters and service relationships: Implications for research,” Journal of Business Research, vol. 20, no. 1, pp. 13-21, 1990. Article (CrossRef Link)

[28] Langeard, E., Bateson, J., Lovelock, C. H. and Eiglier, P., Marketing of services: New insights from consumers and managers, Marketing Science Institute, Cambridge, MA, pp. 81-104, 1981.

[29] Baker, J., Grewal, D. and Parasuraman, A., "The influence of store environment on quality inferences and store image," Journal of the Academy of Marketing Science, Vol. 22, no. 4, pp. 328-339, 1994. Article (CrossRef Link)

[30] Crane, F. G. and Clarke, T. K., "The identification of evaluative criteria and cues used in selecting services,” Journal of Services Marketing, Vol. 2, No. 2, pp. 53-59, 1988. Article (CrossRef Link)

[31] Gronroos, C., Strategic Management and Marketing in the Service Sector, Swedish School of Economics and Business Administration, Helsinfors, Sweden, 1982.

[32] Ko, Y. J. and Pastore, D. L., "A Hierarchial Model of Service Quality for the Recreational Sport Industry,” Sport Marketing Quarterly, Vol. 14, no. 2, pp. 84-97, 2005. Article (CrossRef Link)

[33] WANGCHUK, M. P., "The effects of environment quality, INTQ, OUTQ, and relationship quality on CL in banking industry in Bhutan," doctoral dissertation, University of the Thai Chamber of Commerce, 2008.

[34] Choi, B. J. and Kim, H. S., "The impact of OUTQ, INTQ, and peer-to-peer quality on CS with a hospital service," Managing Service Quality: An International Journal, Vol. 23, No. 3, pp. 188-204, 2013. Article (CrossRef Link)

[35] Sindwani, R. and Goel, M., "The relationship between service quality dimensions, CS and loyalty in technology based self-service banking," International Journal of E-Services and Mobile Applications (IJESMA), vol. 8, no. 2, pp. 54-70, 2016. Article (CrossRef Link) 
[36] Crosby, L. A., Kenneth R. E. and Deborah C., "Relationship quality in services selling: an interpersonal influence perspective," Journal of marketing, Vol. 54, no. 3, pp. 68-81, 1990. Article (CrossRef Link)

[37] De Wulf, K., Odekerken-Schröder, G. and Iacobucci, D., "Investments in consumer relationships: A cross-country and cross-industry exploration,” Journal of marketing, Vol. 65, no. 4, pp. 33-50, 2001. Article (CrossRef Link)

[38] Jarvelin, A. and Lehtinen, U., "Relationship quality in business-to-business service context,” Quis, Vol. 5, pp, 243-354, 1996.

[39] Cho, C. H. and Jeong, W. K., "An effect of website quality on and customer satisfaction, relationship quality and loyalty intention in the internet banking,” The Korea Service Management Society, Vol. 2008, no. 8, pp. 77-102, 2008.

[40] Seo, I. K., Service encounter quality between airline industry and travel agency and its relationship quality influence on structural relationship, doctoral dissertation, Daegu University, 2013.

[41] Kim, H. C. and Shin, J. I., “The effects of relationship quality on customer value and behavioral intention in economy hotels: Focused on Tongyeong," Korea Academic Society of Tourism Management, Vol. 33, no. 4, pp. 201-218, 2018. Article (CrossRef Link)

[42] Oliver, R. L., "Measurement and evaluation of satisfaction processes in retail settings,” Journal of Retailing, 1981.

[43] Kotler, P. and Pfoertsch, W., B2B brand management, Springer Science and Business Media, 2006. Article (CrossRef Link)

[44] Caruana, A., "Service loyalty: The effects of service quality and the mediating role of customer satisfaction,” European Journal of Marketing, Vol. 36, No. 7/8, pp. 811-828, 2002. Article (CrossRef Link)

[45] Dabholkar, P. A., “CS and service quality: Two constructs or one,” Enhancing knowledge development in marketing, Vol. 4, pp. 10-18, 1993.

[46] Iacobucci, D., Grayson, K. A. and Ostrom, A., "The calculus of service quality and CS: theoretical and empirical differentiation and integration,” Advances in Services Marketing and Management, Vol. 3, no. C, pp. 1-67, 1994. Article (CrossRef Link)

[47] Oliver, R. L., "A conceptual model of service quality and service satisfaction: Comparative goals, different concepts,” Advances in service marketing and management, vol. 2, pp. 65-85, 1993.

[48] Dabholkar, P. A., "The convergence of CS and service quality evaluations with increasing customer patronage,” Journal of consumer satisfaction, dissatisfaction and complaining behavior, vol. 8, no. 1, pp. 32-43, 1995.

[49] Kalwani, M. U. and Narayandas, N., "Long-term manufacturer-supplier relationships: do they pay off for supplier firms?,” Journal of Marketing, Vol. 59, no. 1, pp. 1-16, 1995.

Article (CrossRef Link)

[50] Hong, S. N. and Lee, H. J., "Effects of purchasing factors through social-commerce of beauty service on the consumer satisfaction and the repurchasing intention," Journal of Internet Computing and Services, Vol. 15, no. 6, pp. 133-144, 2014. Article (CrossRef Link)

[51] Bodet, G., "CS and loyalty in service: Two concepts, four constructs, several relationships," Journal of Retailing and Consumer Services, Vol. 15, no. 3, pp. 156-162, 2008. Article (CrossRef Link)

[52] Velázquez, B. M., Saura, I. G. and Molina, M. E. R., "Conceptualizing and measuring loyalty: Towards a conceptual model of tourist loyalty antecedents,” Journal of Vacation Marketing, Vol. 17, no. 1, pp. 65-81, 2011. Article (CrossRef Link)

[53] Setiawan, H. and Sayuti, A. J., "Effects of service quality, customer trust and corporate image on CS and loyalty: An assessment of travel agencies customer in South Sumatra Indonesia,” IOSR Journal of Business and Management, Vol. 19, no. 5, pp. 31-40, 2017. Article (CrossRef Link)

[54] Lee, S. T., “A study on effects of experiential value of hotel users for five-star hotels on usage satisfaction and continuous usage intention,” The Journal of the Korea Contents Association, Vol. 19, no. 10, pp. 59-68, 2019. Article (CrossRef Link) 


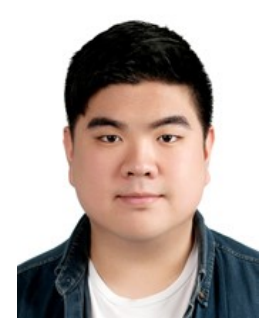

Chulhwan Kwon is currently a Master's student in the School of Business Administration, Soongil University, Seoul, Korea. His current research interests include Operation Management, Service Operation Management, Total Quality Management, and Smart Factories.

chulhk1@hanmail.net

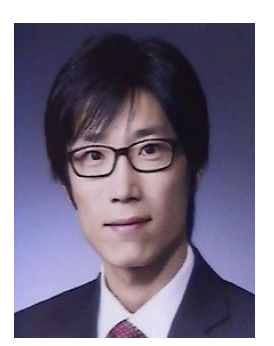

Donghyuk Jo is currently a professor in the School of Business Administration, Soongsil University, Seoul, Korea. His current research interests include Operation Management, Management Science, Technology Management, etc.

joe@ssu.ac.kr

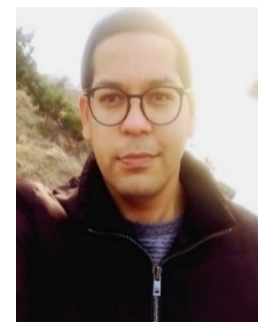

Hugo Guimarães Mariano received his M.S in Business Administration from Soongsil University in 2019. 